\title{
Effect of Integrated Nutrient Management on Nutrient Content and Uptake by Late Sown toria (Brassica campestris var toria) and Availability of Nutrients in the Soil
}

\author{
Priyanki Bora $^{1 *}$, Nayan Jyoti Ojha ${ }^{1}$ and Anjali Basumatary ${ }^{2}$ \\ ${ }^{1}$ Department of Agronomy, ${ }^{2}$ Department of Soil Science, Assam Agricultural University, \\ Jorhat-785013, Assam, India \\ *Corresponding author
}

K e y w o r d s
Integrated nutrient
management,
Nutrient content,
$\begin{aligned} & \text { Nutrient uptake and } \\ & \text { nutrient availability }\end{aligned}$
Article Info
$\begin{aligned} & \text { Accepted: } \\ & 10 \text { November } 2020 \\ & \text { Available Online: } \\ & \text { 10 December } 2020\end{aligned}$

\section{Keywords}

Integrated nutrient

Nutrient content

Nutrient uptake and

Article Info

Accepted:

Available Online:

cember 2020

\section{Introduction}

Integrated nutrient management is a concept, which helps in maintenance of soil fertility and plant nutrient supply in optimum amounts to sustain soil and crop productivity through optimization of the benefits of all the possible sources of plant nutrients in an integral manner. Through integration of both organic, inorganic and biofertilizer sources it provides balance and adequate amount of nutrients. As we know that excess and imbalanced use of nutrients has caused nutrient mining from the soil, deteriorated crop productivity and ultimately soil health. It helps in improving the physical, chemical and biological properties of the soil along with that it ensures the availability of all the essential nutrients that are required for plants. India is in the third rank in rapeseed and mustard production 
after Canada and China with 19.3 per cent area and 11.3 per cent production in the world. In India, it ranked second in cultivation after groundnut among the various oilseed crops which accounted for 25 per cent of total area and one third of total oil production in the country (Shekhawat et al., 2012). In case of Assam, rapeseed and mustard is the main oilseed crop with an annual production of 1.85 lakh tones of seed producing in an area of 2.90 lakh hectares (Anonymous, 2018). Its productivity is only $639 \mathrm{~kg} / \mathrm{ha}$ which is very low as compared to the national average. Rapeseed-mustard requires a relatively large amount of these nutrients to achieve the yield potential but inadequate supply often leads to low productivity. In some areas of medium lowland, sandy loam to clay loam soil, the crop is grown immediately after harvest of sali rice with poor nutrient management which leads to low production of the crop. The application of organic, inorganic nutrient and biofertilizer is beneficial for sustaining the productivity of the crop under late sown condition. Thus, the most logical way to manage long-term fertility and productivity of the soil is integrated use of plant nutrients as balance nutrient is the key component to increase crop yields, which will also take care of the environmental pollution including soil, water and air (Antil and Narwal, 2007). It was reported that yield of mustard crop was significantly increased with continuous balanced application of inorganic (100\% $\mathrm{NPK})+$ lime + biofertilizer + FYM as compared to the control plots (Saha et al., 2010). Increasing levels of vermicompost application increased the content and uptake of N, P, K, S, Zn and Fe in seed and stover of mustard (Gour et al., 2017). Kumar et al., (2018) from their experiment on mustard revealed that the highest nutrient uptake (NPKS) by seed and stover were recorded in the treatment having integration of organic, inorganic and biofertilizer. It was also reported that application of vermicompost along with inorganic fertilizer significantly increased available NPK levels after harvest of mustard (Kansotia et al., 2013). Considering all these facts the present experiment was conducted to study the influence of integrated nutrient management on nutrient content and uptake by late sown toria and the availability of nutrients in the soil after harvest of the crop.

\section{Materials and Methods}

An experiment was carried out at Instructional-cum-Research Farm, AAU, Jorhat during the rabi season of 2017-18 and 2018-19. The soils of the experimental sites were sandy loam in texture, acidic in reaction ( $\mathrm{pH} 5.2$ and 5.5), medium in organic carbon (0.51 and $0.54 \%)$, available $\mathrm{N}$ (315.51 and $328.71 \mathrm{~kg} / \mathrm{ha})$, available $\mathrm{K}_{2} \mathrm{O}(137.5$ and $138.42 \mathrm{~kg} / \mathrm{ha})$ and available $\mathrm{Zn}(0.79$ and 0.95 $\mathrm{mg} / \mathrm{kg})$ while low in available $\mathrm{P}_{2} \mathrm{O}_{5}(17.80$ and $20.45 \mathrm{~kg} / \mathrm{ha}$ ), available $\mathrm{S}$ (16.12 and $19.83 \mathrm{~kg} / \mathrm{ha})$ and available B (0.21 and 0.25 $\mathrm{mg} / \mathrm{kg}$ ) in both the years, respectively. The total rainfall received during the rabi seasons of 2017-18 and 2018-19 was 79.6 and 99.4 $\mathrm{mm}$ respectively. The experiment was done in Randomized Block Design with three replication and consisted of ten treatments. The treatments were $100 \%$ recommended dose of fertilizer (RDF) (40-35-15 kg N-P $\mathrm{O}_{5^{-}}$ $\mathrm{K}_{2} \mathrm{O} / \mathrm{ha}+10 \mathrm{~kg}$ borax/ha $)\left(\mathrm{T}_{1}\right), \mathrm{T}_{1}+$ vermicompost @ 2t/ ha $\left(\mathrm{T}_{2}\right), \mathrm{T}_{2}+20 \mathrm{~kg} \mathrm{~S} / \mathrm{ha}$ $\left(\mathrm{T}_{3}\right), \mathrm{T}_{3}+4 \mathrm{~kg} \mathrm{Zn/ha}\left(\mathrm{T}_{4}\right), \mathrm{T}_{4}+$ seed treatment with biofertilizer consortia $\left(\mathrm{T}_{5}\right), 75 \% \mathrm{RDF}$ ( $\left.\mathrm{T}_{6}\right), \mathrm{T}_{6}+$ vermicompost @ 2t/ ha $\left(\mathrm{T}_{7}\right), \mathrm{T}_{7}+$ $20 \mathrm{~kg} \mathrm{~S} / \mathrm{ha}\left(\mathrm{T}_{8}\right), \mathrm{T}_{8}+4 \mathrm{~kg} \mathrm{Zn/ha}\left(\mathrm{T}_{9}\right), \mathrm{T}_{9}+$ seed treatment with biofertilizer consortia $\left(\mathrm{T}_{10}\right)$. The field was ploughed immediately after the harvest of transplanted kharif rice. Jeuti variety of toria was taken and sown in as per treatment full dose of all the fertilizers and vermicompost except urea were applied by broadcasting and incorporated into the soil one day before sowing. December $1^{\text {st }}$ and $2^{\text {nd }}$ 
week and using seed rate $13 \mathrm{~kg} / \mathrm{ha}$ in $30 \mathrm{~cm}$ rows. The remaining half dose of $\mathrm{N}$ was applied 20 days after sowing along with weed control operation. As per integrated nutrient management treatment $\left(\mathrm{T}_{5}\right.$ and $\left.\mathrm{T}_{10}\right)$, seeds were treated with biofertilizer consortia containing Azotobacter and Azospirillum @ $10 \mathrm{~g} / \mathrm{kg}$ of seeds the night before sowing and were allowed to dry for whole night and sowing was done next day. The plant samples (both seed and stover) collected at harvest from each plot were dried in oven at $60^{\circ} \mathrm{C}$. Grinding of the stover was done in an electric grinder while the seed samples were crushed in pestle and mortar for chemical analysis. After harvesting, the plant samples were oven dried and analyzed for nutrient content in seeds and stover. $\mathrm{N}$ content by (Jackson, 1973) by modified Kjeldahl method, $\mathrm{P}$ content by tri-acid digestion and yellow color method (Jackson, 1973), K content by (Jackson, 1973) by flame photometer, S content by Turbidemetric method (Tabatabai and Bremne, 1970), Zn content by Atomic Absorption Spectrophotometer and Boron content by Azomethine-H method were analyzed.

The nutrient uptake by seed and stover were calculated by standard formula and then total uptake was calculated by adding the uptakes in seeds and stover. For soil analysis, soil samples collected from each plot after harvest were air dried, grounded and sieved through 2 $\mathrm{mm}$ diameter sieve and were used for estimation of available NPKS which were expressed in $\mathrm{kg} / \mathrm{ha}$ and $\mathrm{Zn}$ and boron were expressed in $\mathrm{mg} / \mathrm{kg}$, respectively. Available nitrogen was estimated by Modified Kjeldahl method, available phosphorus by Bray I method, available potassium by Flame photometric method, available sulphur by Turbidemetric method, available zinc by DTPA method and available boron by Azomethine-H method. Data were analyzed statistically at using Microsoft Excel.
Parameters like Critical Difference (CD) at 5 $\%$ level (for test of significance), SEM i.e. Standard Error Mean were calculated.

\section{Results and Discussion}

\section{Nutrient content in seeds and stover and total nutrient uptake by toria}

The nutrients contents in seed and stover and their uptake was affected due to integrated nutrient management treatments in both the years. Table 1 and 2 depicted that the highest nutrient content in seed and stover and uptake of nutrients (N, P, K, S, Zn and B) by plants were recorded in treatment comprising of $100 \% \mathrm{RDF}+$ vermicompost @ $2 \mathrm{t} / \mathrm{ha}+20 \mathrm{~kg}$ $\mathrm{S} / \mathrm{ha}+4 \mathrm{~kg} \mathrm{Zn/ha}+$ seed treatment with biofertilizers $\left(\mathrm{T}_{5}\right)$. The maximum values of nutrient uptake obtained under the treatment $\mathrm{T}_{5}$ since, uptake of nutrient is the function of seed and stover yield and their concentration and higher concentration of these nutrients coupled with increased seed and stover yield enhanced the total uptake.

The treatment $T_{5}$ resulted in higher nutrient uptake which might be due to consistent supply of nutrients and reduced rate of loss of releasing nutrients during the process of decomposition of organic manure i.e. vermicompost and addition of biofertilizers that helped in nutrient availability. Moreover, due to improved root growth and its increased functional activity this might have helped in greater extraction of nutrients and improved the concentration of nutrient in plant. This finding was in agreement with the report of Kumar et al., (2016) where they reported that when NPK was integrated with vermicompost $2 \mathrm{t} / \mathrm{ha}+\mathrm{S}(40 \mathrm{~kg} / \mathrm{ha})+\mathrm{ZnSO}_{4}(25 \mathrm{~kg} / \mathrm{ha})+$ boron $(1 \mathrm{~kg} / \mathrm{ha})$ and seed inoculation with Azotobacter @ $10 \mathrm{~g} / \mathrm{kg}$ of seed in Indian mustard also improved uptake of $\mathrm{N}, \mathrm{P}, \mathrm{K}, \mathrm{S}$, $\mathrm{Zn}$ and $\mathrm{B}$. 
Table.1 Effect of integrated nutrient management on nutrient content in seeds of toria

\begin{tabular}{|c|c|c|c|c|c|c|c|c|c|c|c|c|}
\hline \multirow[t]{2}{*}{ Treatments } & \multicolumn{2}{|c|}{$\begin{array}{c}\text { Nitrogen content } \\
(\%)\end{array}$} & \multicolumn{2}{|c|}{$\begin{array}{l}\text { Phosphorus } \\
\text { content }(\%)\end{array}$} & \multicolumn{2}{|c|}{$\begin{array}{c}\text { Potassium } \\
\text { content }(\%)\end{array}$} & \multicolumn{2}{|c|}{$\begin{array}{c}\text { Sulphur content } \\
(\%)\end{array}$} & \multicolumn{2}{|c|}{$\begin{array}{l}\text { Zinc content } \\
(\mathrm{mg} / \mathrm{kg})\end{array}$} & \multicolumn{2}{|c|}{$\begin{array}{c}\text { Boron content } \\
(\mathrm{mg} / \mathrm{kg})\end{array}$} \\
\hline & $\begin{array}{c}2017- \\
18\end{array}$ & $\begin{array}{c}2018- \\
19\end{array}$ & $\begin{array}{c}2017- \\
18\end{array}$ & $\begin{array}{c}2018- \\
19\end{array}$ & $\begin{array}{c}2017- \\
18\end{array}$ & $\begin{array}{c}2018- \\
19\end{array}$ & $\begin{array}{c}2017- \\
18\end{array}$ & $\begin{array}{c}2018- \\
19\end{array}$ & $\begin{array}{c}2017- \\
18\end{array}$ & $\begin{array}{c}2018- \\
19\end{array}$ & $\begin{array}{c}2017- \\
18\end{array}$ & $\begin{array}{c}2018- \\
19\end{array}$ \\
\hline $\mathbf{T}_{1}$ & 2.13 & 2.14 & 0.44 & 0.45 & 0.36 & 0.38 & 0.35 & 0.37 & 36.03 & 37.37 & 24.07 & 25.03 \\
\hline $\mathbf{T}_{2}$ & 2.14 & 2.17 & 0.45 & 0.46 & 0.36 & 0.39 & 0.37 & 0.39 & 39.02 & 39.98 & 24.33 & 24.68 \\
\hline $\mathbf{T}_{\mathbf{3}}$ & 2.16 & 2.19 & 0.47 & 0.48 & 0.37 & 0.39 & 0.40 & 0.41 & 40.02 & 41.07 & 25.03 & 26.07 \\
\hline $\mathbf{T}_{4}$ & 2.20 & 2.22 & 0.51 & 0.52 & 0.41 & 0.43 & 0.42 & 0.44 & 42.70 & 44.04 & 27.02 & 28.02 \\
\hline $\mathbf{T}_{5}$ & 2.26 & 2.27 & 0.53 & 0.54 & 0.44 & 0.47 & 0.44 & 0.45 & 45.04 & 47.10 & 27.67 & 28.70 \\
\hline $\mathbf{T}_{6}$ & 2.01 & 2.04 & 0.42 & 0.43 & 0.31 & 0.33 & 0.31 & 0.33 & 33.04 & 34.07 & 22.02 & 22.68 \\
\hline $\mathbf{T}_{7}$ & 2.08 & 2.11 & 0.43 & 0.44 & 0.34 & 0.35 & 0.33 & 0.34 & 35.03 & 37.04 & 23.03 & 23.69 \\
\hline $\mathbf{T}_{8}$ & 2.11 & 2.12 & 0.44 & 0.44 & 0.36 & 0.37 & 0.35 & 0.37 & 37.01 & 39.03 & 25.67 & 26.68 \\
\hline $\mathbf{T}_{9}$ & 2.17 & 2.19 & 0.46 & 0.47 & 0.37 & 0.37 & 0.37 & 0.38 & 41.03 & 41.69 & 26.03 & 27.04 \\
\hline $\mathbf{T}_{10}$ & 2.18 & 2.20 & 0.48 & 0.48 & 0.38 & 0.40 & 0.40 & 0.42 & 42.34 & 44.01 & 27.01 & 27.05 \\
\hline $\operatorname{S.Em}( \pm)$ & 0.02 & 0.01 & 0.007 & 0.007 & 0.007 & 0.007 & 0.007 & 0.007 & 0.61 & 0.87 & 0.45 & 0.46 \\
\hline CD (5\%) & 0.06 & 0.04 & 0.03 & 0.03 & 0.02 & 0.03 & 0.02 & 0.02 & 1.80 & 2.62 & 1.32 & 1.40 \\
\hline
\end{tabular}


Table.2 Effect of integrated nutrient management on nutrient content in stover of toria

\begin{tabular}{|c|c|c|c|c|c|c|c|c|c|c|c|c|}
\hline \multirow[t]{2}{*}{ Treatments } & \multicolumn{2}{|c|}{$\begin{array}{c}\text { Nitrogen content } \\
(\%)\end{array}$} & \multicolumn{2}{|c|}{$\begin{array}{l}\text { Phosphorus } \\
\text { content }(\%)\end{array}$} & \multicolumn{2}{|c|}{$\begin{array}{c}\text { Potassium } \\
\text { content }(\%)\end{array}$} & \multicolumn{2}{|c|}{$\begin{array}{c}\text { Sulphur content } \\
(\%)\end{array}$} & \multicolumn{2}{|c|}{$\begin{array}{l}\text { Zinc content } \\
(\mathrm{mg} / \mathrm{kg})\end{array}$} & \multicolumn{2}{|c|}{$\begin{array}{c}\text { Boron content } \\
(\mathrm{mg} / \mathrm{kg})\end{array}$} \\
\hline & $\begin{array}{c}2017- \\
18\end{array}$ & $\begin{array}{c}2018- \\
19\end{array}$ & $\begin{array}{c}2017- \\
18\end{array}$ & $\begin{array}{c}2018- \\
19\end{array}$ & $\begin{array}{c}2017- \\
18\end{array}$ & $\begin{array}{c}2018- \\
19\end{array}$ & $\begin{array}{c}2017- \\
18\end{array}$ & $\begin{array}{c}2018- \\
19\end{array}$ & $\begin{array}{c}2017- \\
18\end{array}$ & $\begin{array}{c}2018- \\
19\end{array}$ & $\begin{array}{c}2017- \\
18\end{array}$ & $\begin{array}{c}2018- \\
19\end{array}$ \\
\hline $\mathbf{T}_{1}$ & 0.54 & 0.57 & 0.13 & 0.14 & 0.54 & 0.55 & 0.15 & 0.17 & 17.02 & 19.07 & 21.02 & 21.34 \\
\hline $\mathbf{T}_{2}$ & 0.55 & 0.58 & 0.13 & 0.14 & 0.55 & 0.57 & 0.17 & 0.18 & 17.33 & 19.01 & 21.33 & 22.38 \\
\hline $\mathbf{T}_{\mathbf{3}}$ & 0.58 & 0.61 & 0.14 & 0.14 & 0.57 & 0.58 & 0.18 & 0.19 & 19.99 & 20.37 & 22.33 & 23.02 \\
\hline $\mathbf{T}_{4}$ & 0.60 & 0.62 & 0.16 & 0.18 & 0.62 & 0.63 & 0.20 & 0.21 & 21.99 & 24.07 & 24.03 & 25.01 \\
\hline $\mathbf{T}_{5}$ & 0.65 & 0.66 & 0.17 & 0.18 & 0.64 & 0.66 & 0.21 & 0.23 & 24.03 & 26.38 & 25.03 & 25.68 \\
\hline $\mathbf{T}_{6}$ & 0.51 & 0.51 & 0.12 & 0.13 & 0.53 & 0.54 & 0.13 & 0.15 & 15.03 & 17.06 & 20.07 & 20.80 \\
\hline $\mathbf{T}_{7}$ & 0.53 & 0.55 & 0.12 & 0.13 & 0.54 & 0.55 & 0.15 & 0.16 & 17.03 & 18.40 & 20.33 & 21.40 \\
\hline $\mathbf{T}_{8}$ & 0.54 & 0.57 & 0.13 & 0.14 & 0.54 & 0.56 & 0.16 & 0.18 & 18.03 & 19.40 & 21.13 & 22.35 \\
\hline $\mathbf{T}_{9}$ & 0.57 & 0.58 & 0.13 & 0.14 & 0.56 & 0.57 & 0.17 & 0.19 & 19.68 & 21.04 & 22.01 & 22.68 \\
\hline $\mathbf{T}_{10}$ & 0.60 & 0.62 & 0.14 & 0.15 & 0.61 & 0.62 & 0.19 & 0.20 & 21.68 & 22.73 & 24.03 & 24.71 \\
\hline $\operatorname{S.Em}( \pm)$ & 0.01 & 0.01 & 0.007 & 0.007 & 0.01 & 0.007 & 0.007 & 0.007 & 0.84 & 0.82 & 0.61 & 0.39 \\
\hline CD (5\%) & 0.05 & 0.04 & 0.02 & 0.02 & 0.04 & 0.04 & 0.02 & 0.01 & 2.51 & 2.44 & 1.81 & 1.18 \\
\hline
\end{tabular}


Table.3 Effect of integrated nutrient management on total nutrient uptake by toria

\begin{tabular}{|c|c|c|c|c|c|c|c|c|c|c|c|c|}
\hline \multirow[t]{2}{*}{ Treatments } & \multicolumn{2}{|c|}{$\begin{array}{c}\text { Nitrogen uptake } \\
(\mathrm{kg} / \mathrm{ha})\end{array}$} & \multicolumn{2}{|c|}{$\begin{array}{c}\text { Phosphorus } \\
\text { uptake (kg/ha) }\end{array}$} & \multicolumn{2}{|c|}{$\begin{array}{c}\text { Potassium } \\
\text { uptake } \\
\text { (kg/ha) }\end{array}$} & \multicolumn{2}{|c|}{$\begin{array}{c}\text { Sulphur uptake } \\
\text { (kg/ha) }\end{array}$} & \multicolumn{2}{|c|}{$\begin{array}{l}\text { Zinc uptake } \\
\text { (g/ha) }\end{array}$} & \multicolumn{2}{|c|}{$\begin{array}{c}\text { Boron uptake } \\
\text { (g/ha) }\end{array}$} \\
\hline & $\begin{array}{c}2017- \\
18\end{array}$ & $\begin{array}{c}2018- \\
19\end{array}$ & $\begin{array}{c}2017- \\
18\end{array}$ & $\begin{array}{c}2018- \\
19\end{array}$ & $\begin{array}{c}2017- \\
18\end{array}$ & $\begin{array}{c}2018- \\
19\end{array}$ & $\begin{array}{c}2017- \\
18\end{array}$ & $\begin{array}{c}2018- \\
19\end{array}$ & $\begin{array}{c}2017- \\
18\end{array}$ & $\begin{array}{c}2018- \\
19\end{array}$ & $\begin{array}{c}2017- \\
18\end{array}$ & $\begin{array}{c}2018- \\
19\end{array}$ \\
\hline $\mathbf{T}_{1}$ & 23.13 & 24.51 & 5.08 & 5.50 & 11.39 & 11.96 & 4.81 & 5.44 & 52.20 & 58.17 & 50.88 & 53.52 \\
\hline $\mathbf{T}_{2}$ & 26.15 & 27.77 & 5.76 & 6.19 & 12.69 & 13.56 & 5.87 & 6.45 & 60.84 & 66.56 & 56.97 & 60.57 \\
\hline $\mathbf{T}_{\mathbf{3}}$ & 28.58 & 30.03 & 6.47 & 6.71 & 13.87 & 14.50 & 6.74 & 7.10 & 70.61 & 73.77 & 62.88 & 66.35 \\
\hline $\mathbf{T}_{4}$ & 31.84 & 34.21 & 7.82 & 8.78 & 16.73 & 17.78 & 7.93 & 8.78 & 83.79 & 93.43 & 74.54 & 80.75 \\
\hline $\mathbf{T}_{5}$ & 35.91 & 38.41 & 8.78 & 9.67 & 18.47 & 19.95 & 8.82 & 9.89 & 96.28 & 108.80 & 82.14 & 88.29 \\
\hline $\mathbf{T}_{6}$ & 18.98 & 19.71 & 4.18 & 4.50 & 9.74 & 10.18 & 3.75 & 4.27 & 41.18 & 45.95 & 42.74 & 45.04 \\
\hline $\mathbf{T}_{7}$ & 22.38 & 23.44 & 4.79 & 5.14 & 10.92 & 11.34 & 4.60 & 5.00 & 50.72 & 55.32 & 48.00 & 51.05 \\
\hline $\mathbf{T}_{8}$ & 24.58 & 25.69 & 5.42 & 5.72 & 11.94 & 12.52 & 5.26 & 5.92 & 57.93 & 62.86 & 55.05 & 58.77 \\
\hline $\mathbf{T}_{9}$ & 27.15 & 28.22 & 5.91 & 6.35 & 13.25 & 13.71 & 6.03 & 6.66 & 67.93 & 72.64 & 60.87 & 64.20 \\
\hline $\mathbf{T}_{10}$ & 30.01 & 31.79 & 6.76 & 7.25 & 15.43 & 16.35 & 7.25 & 7.80 & 78.55 & 85.14 & 70.72 & 74.72 \\
\hline $\operatorname{S.Em}( \pm)$ & 0.86 & 0.77 & 0.23 & 0.26 & 0.31 & 0.36 & 0.18 & 0.18 & 2.21 & 2.17 & 1.71 & 1.32 \\
\hline CD $(5 \%)$ & 2.54 & 2.31 & 0.69 & 0.73 & 0.95 & 1.07 & 0.56 & 0.55 & 6.57 & 6.45 & 5.08 & 3.96 \\
\hline
\end{tabular}


Table.4 Effect of integrated nutrient management on available nutrients in soil after harvest of toria

\begin{tabular}{|c|c|c|c|c|c|c|c|c|c|c|c|c|}
\hline \multirow[t]{2}{*}{ Treatment } & \multicolumn{2}{|c|}{$\begin{array}{c}\text { Available N } \\
\text { (kg/ha) }\end{array}$} & \multicolumn{2}{|c|}{$\begin{array}{c}\text { Available } \mathrm{P}_{2} \mathrm{O}_{5} \\
\text { (kg/ha) }\end{array}$} & \multicolumn{2}{|c|}{$\begin{array}{c}\text { Available } K_{2} O \\
(\mathrm{~kg} / \mathrm{ha})\end{array}$} & \multicolumn{2}{|c|}{$\begin{array}{c}\text { Available S } \\
\text { (kg/ha) }\end{array}$} & \multicolumn{2}{|c|}{$\begin{array}{c}\text { Available Zn } \\
\text { (mg/kg) }\end{array}$} & \multicolumn{2}{|c|}{$\begin{array}{c}\text { Available B } \\
\text { (mg/kg) }\end{array}$} \\
\hline & $\begin{array}{c}2017- \\
18\end{array}$ & $\begin{array}{c}2018- \\
19\end{array}$ & $\begin{array}{c}2017- \\
18\end{array}$ & $\begin{array}{c}2018- \\
19\end{array}$ & $\begin{array}{c}2017- \\
18\end{array}$ & $\begin{array}{c}2018- \\
19\end{array}$ & $\begin{array}{c}2017- \\
18\end{array}$ & $\begin{array}{c}2018- \\
19\end{array}$ & $\begin{array}{c}2017- \\
18\end{array}$ & $\begin{array}{c}2018- \\
19\end{array}$ & $\begin{array}{c}2017- \\
18\end{array}$ & $\begin{array}{c}2018- \\
19\end{array}$ \\
\hline $\mathbf{T}_{1}$ & 318.76 & 320.25 & 20.18 & 22.12 & 121.52 & 123.17 & 11.72 & 13.51 & 0.79 & 0.80 & 0.254 & 0.254 \\
\hline $\mathbf{T}_{2}$ & 327.37 & 331.01 & 21.32 & 22.68 & 121.88 & 124.29 & 11.89 & 13.59 & 1.08 & 1.09 & 0.256 & 0.256 \\
\hline $\mathbf{T}_{\mathbf{3}}$ & 333.89 & 335.68 & 22.55 & 24.39 & 125.14 & 126.15 & 12.54 & 14.26 & 1.24 & 1.24 & 0.259 & 0.260 \\
\hline $\mathbf{T}_{4}$ & 339.99 & 343.00 & 23.85 & 25.75 & 129.20 & 130.73 & 14.31 & 17.41 & 1.37 & 1.38 & 0.263 & 0.264 \\
\hline $\mathbf{T}_{5}$ & 349.28 & 355.43 & 26.66 & 27.26 & 134.22 & 135.07 & 16.21 & 19.48 & 1.39 & 1.41 & 0.265 & 0.266 \\
\hline $\mathbf{T}_{6}$ & 307.73 & 311.24 & 19.25 & 21.03 & 117.07 & 118.12 & 10.78 & 11.90 & 0.74 & 0.75 & 0.250 & 0.250 \\
\hline $\mathbf{T}_{7}$ & 311.88 & 316.29 & 20.80 & 22.25 & 120.04 & 121.35 & 11.42 & 12.98 & 0.83 & 0.84 & 0.251 & 0.254 \\
\hline $\mathbf{T}_{8}$ & 324.84 & 325.28 & 21.24 & 23.12 & 120.67 & 122.89 & 12.15 & 13.37 & 1.21 & 1.25 & 0.258 & 0.260 \\
\hline $\mathbf{T}_{9}$ & 330.76 & 337.57 & 22.19 & 23.22 & 124.00 & 125.67 & 12.28 & 15.14 & 1.29 & 1.30 & 0.260 & 0.261 \\
\hline $\mathbf{T}_{10}$ & 338.85 & 342.28 & 23.21 & 24.44 & 127.00 & 128.00 & 13.10 & 16.11 & 1.35 & 1.36 & 0.262 & 0.263 \\
\hline $\operatorname{S.Em}( \pm)$ & 2.48 & 1.65 & 0.97 & 0.98 & 1.63 & 0.91 & 0.65 & 0.52 & 0.03 & 0.02 & 0.0002 & 0.0007 \\
\hline CD $(5 \%)$ & 7.37 & 4.92 & 2.88 & 2.91 & 4.85 & 2.71 & 1.94 & 1.57 & 0.06 & 0.03 & 0.001 & 0.002 \\
\hline
\end{tabular}


The recommended fertilizers combined with application of FYM $+\mathrm{ZnSO}_{4}+$ seed treatment with Azotobacter gave the highest N, P, K, S and $\mathrm{Zn}$ content as well as their uptake in seed and stover of mustard was also reported by Singh et al., (2010). Gour et al., (2017) reported that combine application of recommended dose of NPK along with S, Zn and $\mathrm{Fe}$ fertilization increased content and uptake of nitrogen, phosphorus, potassium, sulphur, zinc and iron in seed and stover of Indian mustard.

\section{Available nutrient content in soil after harvest}

The influence of integrated nutrient management treatment was found to be significant in case of available soil $\mathrm{N}, \mathrm{P}_{2} \mathrm{O}_{5}$, $\mathrm{K}_{2} \mathrm{O}, \mathrm{Zn}, \mathrm{S}$ and $\mathrm{B}$ after harvest of the late sown toria. Among the various treatments, the treatment having $100 \% \mathrm{RDF}+$ vermicompost@2 t/ha $+20 \mathrm{~kg} \mathrm{~S} / \mathrm{ha}+4 \mathrm{~kg}$ $\mathrm{Zn} / \mathrm{ha}+$ seed treatment with biofertilizer consortia $\left(\mathrm{T}_{5}\right)$ gave the highest available $\mathrm{N}$, $\mathrm{P}_{2} \mathrm{O}_{5}, \mathrm{~K}_{2} \mathrm{O}, \mathrm{Zn}, \mathrm{S}$ and $\mathrm{B}$ in soil (Table 3). Integration of nutrients through organic, inorganic and bio fertilizer used in suitable combination might have improved the soil fertility and greater nutrient availability. Kumar et al., (2018) reported that maximum available soil nutrient (NPK and S) by integration of $50 \% \mathrm{RDF}+\mathrm{FYM} 6 \mathrm{t} / \mathrm{ha}+$ vermicompost $2 \mathrm{t} / \mathrm{ha}+$ biofertilizer in mustard plot after harvest. Yadav et al., (2010) also reported that in mustard plot when $S$ and biofertilizers were applied alone or with conjunction with each other, increased the available NPK and S content in the soil. Similar results were also found by Kansotia et al., (2013) in Indian mustard (Table 4).

From the two year investigation, it can be concluded that combine application of $100 \%$ $\mathrm{RDF}$ with vermicompost, $\mathrm{S}, \mathrm{Zn}$ and biofertilizer consortia not only enhances the nutrient content of seeds and stover and total uptake of nutrients by toria but also increases the available nutrients in the soil after harvest of the crop.

\section{References}

Anonymous. 2018. Statistical Hand Book, Assam. Directorate of Economics and Statistics, Government of Assam.

Antil, R.S. and Narwal, R.P. 2007. Integrated nutrient management for sustainable soil health and crop productivity. Indian J. Fertili. 3(9): 111-121.

Gour, M.K., Choudhary, R. and Jat, B.L. 2017. Influence of vermicompost and different nutrients on performance of Indian mustard [Brassica juncea (L.) Czern and Coss] in Typic Haplustepts. Asian J. Bio. Sci. 12(2):165-184.

Jackson, M.L. 1973. In: Soil chemical analysis. Pub. Prentica Hall of India Pvt. Ltd., New Delhi.

Kansotia, B.C., Meena, R.S. and Meena, V.S. 2013. Effect of vermicompost and inorganic fertilizers on Indian mustard (Brassica juncea L.). Asian J. Soil Sci. 8(1): 136-139.

Kumar, S., Kumar, S., Kumar, A. and Singh, O. 2016. Productivity, profitability and quality of Indian mustard (Brassica juncea) as influenced by fertilizer levels and integrated nutrient-management. Indian J. Agron. 61(2): 231-236.

Kumar, S., Kumar, S., Kumar, A. and Singh, O. 2016. Productivity, profitability and quality of Indian mustard (Brassica juncea) as influenced by fertilizer levels and integrated nutrient-management. Indian J. Agron. 61(2): 231-236.

Kumar, S., Yadav, K.G., Goyal, G., Kumar, R. and Kumar, A. 2018. Effect of organic and inorganic sources of nutrients on growth and yield attributing characters of mustard crop (Brassica juncea L.). Inter. J. Chemical Stud. 6(2): 2306-2309. 
Saha, R., Mishra,V.K., Majumdar, B., Laxminarayana, K. and Ghosh, P.K. (2010). Effect of integrated nutrient management on soil physical properties and crop productivity under a maize (Zea mays)-mustard (Brassica compestris) cropping sequence in acidic soils of North East India. Communi. Soil Sci. Plant Analy. 41: 2187-2200.

Shekhawat, K., Rathore, S.S., Premi, O.P., Kandpal, B.K. and Chauhan, J.S. 2012. Advance in agronomic management of Indian mustard (Brassica juncea (L.) Czernj. Cosson): An Overview. Inter. J. Agron. 14.

Singh, S.P., Pal, M.S. and Dube, S.N. 2010.
Yield, quality and nutrient uptake of mustard (Brassica juncea) with organic and inorganic fertilization. Curr. $A d v$. Agric. Sci. 2(2): 87-90.

Tabatabi, M. A. and Bremmer, J. M. 1970. A simple turbidimetric method of determining total sulfur in plant materials. Agron. J. 62: 805-806.

Yadav, H.K., Thomas, T. and Khajaria, V. 2010. Effect of different level of sulphur and biofertilizer on the yield of Indian mustard (Brassica juncea L.) and soil properties. J. Agric. Physics. 10: $61-65$.

\section{How to cite this article:}

Priyanki Bora, Nayan Jyoti Ojha and Anjali Basumatary. 2020. Effect of Integrated Nutrient Management on Nutrient Content and Uptake by Late Sown toria (Brassica campestris var toria) and Availability of Nutrients in the Soil. Int.J.Curr.Microbiol.App.Sci. 9(12): 920-928. doi: https://doi.org/10.20546/ijcmas.2020.912.111 